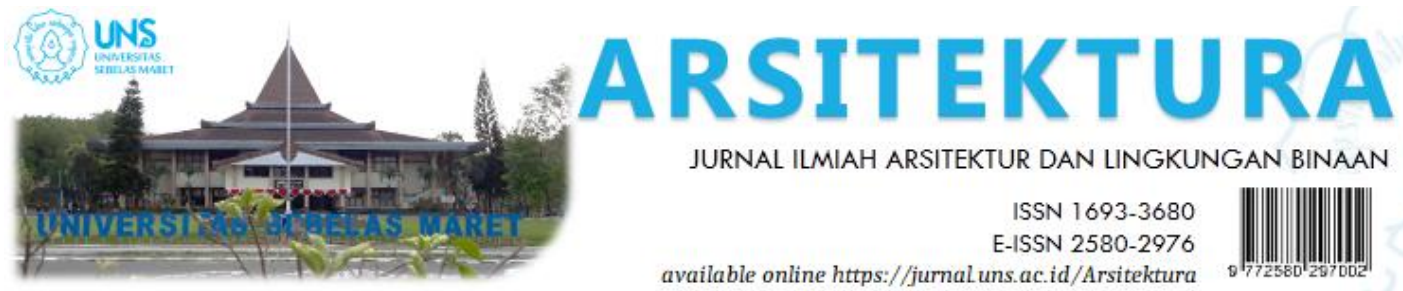

Volume 18 Issue 2 October 2020, pages:215-226

\title{
Ketersediaan Ruang Terbuka Hijau di Kelurahan Lembo Kota Makassar
}

\section{The Availability of Open Green Space in Lembo of Makassar City}

\author{
Paraswatih $^{1 *}$, Nursyam AS ${ }^{2}$, Fadhil Surur ${ }^{3}$ \\ Urban and Regional Department, Faculty of Science and Technology Alauddin Islamic State University ${ }^{1 *}$ \\ faraswati21@gmail.com \\ Urban and Regional Department, Faculty of Science and Technology Ala uddin Islamic State University ${ }^{2,3}$
}

DOI: https://doi.org/10.20961/arst.v 18i2.41185

Received: April 16, 2020 Revised: July 30,2020 Accepted: August 5, 2020 Available online:October 31, 2020

\begin{abstract}
Green open space in Makassar Citywas decreasing due to population growth and high land demand. The phenomenon that occured was that land use as a green open space was decreasing due to an increase in built space. This study aimed to determine the availability of green open space in the Lembo Village, Tallo District, Makassar. Qualitative descriptive analysis and superimpose analysis were used to determine the availability of green open space in that area. The results showed that public and private green open spaces were available in that area with an area of $18.12 \mathrm{Ha}$ or equivalent to $33.56 \%$ of the total area. The green open space was at least $30 \%$ of the total area, this condition shows sustainability.
\end{abstract}

Keywords: green open space, urban, avaibility

\section{PENDAHULUAN}

Kawasan perkotaan di Indonesia pada saat ini mengalami permasalahan pada tingginya tingkat pertumbuhan penduduk akibat arus urbanisasi sehingga menyebabkan meningkatnya permintaan akan lahan-lahan di perkotaan sebagai tempat tinggal dan aktivitas lainnya (Widyaastuti, 2012). Hal itu menyebabkan ruang-ruang terbuka di perkotaan dan pengelolaan untuk ruang kota semakin berat (Fahreza \& Restu, 2016).

Meningkatnya pembangunan fisik kota, pertumbuhan penduduk serta berbagai aktivitas kota menyebabkan berkurangnya RTH dan menurunnya kualitas lingkungan hidup yang mengakibatkan terjadinya perubahan ekosistem alami (Hadmaja \& Kuspriyanto, 2014).
Keberadaan dari vegetasi yang berada di RTH dapat mempengaruhi kondisi atmosfer setempat, mampu menurunkan suhu dan kelembaban udara juga mengurangi kecepatan angin. Sehingga berkurangnya daerah hijau atau ruang-ruang kosong yang ditumbuhi pepohonan di daerah perkotaan akan membuat dampak-dampak negatif pada kawasan tesebut antara lain polusi udara, berkurangnya debit sumber air untuk kebutuhan penduduk, banjir dan suhu kota semakin panas (Martopo \& Fandeli, 1995).

Semakin meningkatnya pertumbuhan pembangunan di kawasan perkotaan yang tidak melihat dari sisi lingkungannya akan mengakibatkan kawasan yang kumuh dan tidak teratur. Maka dari itu pertumbuhan 
pembangunan harus diselaraskan dengan pembangunan RTH agar tercipta manfaat yang maksimal (Yanti, 2016).

Penyediaannya di suatu kota tidak hanya selalu dari pemerintah, seperti penyediaan taman kota, jalur hijau, dan lainnya (Santoso, Hidayah, \& Sumardjito, 2012). Namun, dapat dilakukan di lahan privat milik masyarakat atau swasta. Salah satu bentuk peran serta masyarakat dalam penyediaannya adalah keberadaan RTH pemukiman, baik dalam bentuk taman lingkungan maupun penghijauan pekarangan (Muta'ali, 2012). Penyelenggaraan RTH di pemukiman, terutama di perkotaan, dapat berfungsi secara estetis, hidrologis, klimatologis, protektif maupun sosial budaya Hastuti (2011) dalam Fahreza \& Restu (2016).

Penyediaan RTH dalam kaitannya dengan permukiman perkotaan dibangun untuk dapat mendukung terbentuknya seluruh elemen dasar permukiman sehingga berperan dalam menciptakan human settlement. Kondisi ini dapat diartikan sebagai permukiman atau bagian dari kota sebagai tempat bermukim manusia dengan segala kehidupannya yang didukung elemen dasar permukiman yaitu shells (rumah), networks (jaringan prasarana), nature (alam), man (manusia) dan society (Susilowati \& Nurini, 2013). Sehingga jika dihubungkan dengan RTH permukiman perkotaan, maka RTH menjadi salah satu unsur pembentuk dalam menciptkan elemen alam dan masyarakat dalam skala tertentu (Soewarno, 2000).

Kota Makassar dengan kondisi pertumbuhan penduduk dan permintaan lahan yang tinggi menyebabkan kehadiran RTH semakin berkurang, padahal ruang terbuka publik merupakan salah satu fasilitas yang penting bagi keberlangsungan pertumbuhan kota ditinjau dari sudut sosiologisnya. Keberadaan kawasan perumahan yang memberikan kontribusi besar pada pencitraan visual Kota Makassar dewasa ini juga mengalami degradasi dalam hal pengelolaan RTH dan ruang-ruang publik lainnya.

Pemanfaatan lahan kota yang yang terus tumbuh dan bersifat akseleratif untuk pembangunan berbagai fasilitas perkotaan, termasuk kemajuan teknologi, industri, dan transportasi, selain sering merubah konfigurasi alami lahan/bentang alam perkotaan juga menyita lahan-lahan tersebut dan berbagai bentukan ruang terbuka lainnya. Kedua hal ini umumnya merugikan keberadaan RTH yang sering dianggap sebagai lahan cadangan dan tidak ekonomis (Departemen Pekerjaan Umum, 2005). Pada beberapa kawasan perumahan memilih ruang terbuka yang secara kuantitas dan kualitas tidak memenuhi persyaratan sebagaimana yang diatur dalam Peraturan Menteri Pekerjaan Umum Nomor: 05/Prt/M/2008 Tentang Pedoman Penyediaan dan Pemanfaatan Lahan RTH di Kawasan Perkotaan.

Ketersediaan Ruang Terbuka Hijau khususnya pada wilayah perkotaan sangat penting mengingat besarnya manfaat yang diperoleh dari keberadaan RTH tersebut. Kawasan Ruang Terbuka Hijau ini juga merupakan tempat interaksi sosial bagi masyarakat yang dapat mengurangi tingkat stres akibat beban kerja dan menjadi tempat rekreasi keluarga bagi masyarakat perkotaan (Arifin, 2014). RTH berperan dalam menciptakan kreativitas dan aktivitas motorik masyarakat yang memerlukan sosialisasi secara periodik dan berkelanjutan untuk mengajak masyarakat memanfaatkan taman sebagai wadah berinteraksi dan berkreativitas secara positif (Sugiyanto \& Sitohang, 2017).

Hal ini juga terjadi di Kelurahan Lembo, Kecamatan Tallo Kota Makassar merupakan salah satu kelurahan dengan tingkat kepadatan penduduk yang tinggi $89.054 \mathrm{~km}^{2}$ dengan jumlah penduduk sebesar 11.577 jiwa, menyebabkan ketersediaan lahan untuk RTH semakin sedikit, sehingga saat musim hujan semakin besar aliran permukaan yang ditemukan, sedangkan kemampuan lahan untuk menahan air hujan semakin berkurang.

Fenomena yang terjadi pada saat ini adalah permasalahan antara ketersediaan dengan pemanfaatan RTH yang ditandai dengan meningkatnya ruang terbangun sehingga berkurangnya RTH. Peningkatan aliran permukaan dan berkurangnya air yang meresap ke dalam tanah. Sehingga berdampak pada tergenangnya air pada area tertentu karena tidak adanya ruang terbuka yang mempercepat penyerapan air permukaan (Salikha, 2012). Pada kondisi tertentu, jumlah air yang tidak 
terserap tersebut menyebabkan banjir. Semakin rendah luasan RTH kota yang tersedia dan semakin tidak maksimal pemafaatannya untuk penerapan subreservoir air hujan maka kecenderungan penambahan debit banjir di permukiman semakin besar (Sabridi, 2012). Dampak lain yang timbul adalah kurangnya area publik yang dapat dimanfaatkan oleh masyarakat serta kondisi lanskap wilayah yang tidak mampu menyeimbangkan temperatur udara. Maka dari itu keberadaan RTH berperan penting dalam pengembangan tata ruang di Kelurahan Lembo Kota Makassar. Dalam mempertegas peran dari RTH tersebut maka langkah yang dapat diambil adalah dengan menilai seberapa besar ketersediaan RTH di Kelurahan Lembo. Secara umum tujuan dari penelitian adalah menganalisis ketersediaan RTH di Kelurahan Lembo Kecamatan Tallo Kota Makassar.

\section{METODE}

Jenis penelitian ini bersifat deskriptif kuantitatif atau penelitian terapan yang di dalamnya mencakup penelitian survei dengan pendekatan kualitatif yaitu penelitian non matematis dengan proses menghasilkan data-data dari hasil temuan berupa pengamatan survei (Ikhsan \& Aida, 2011). Adapun penelitian kuantitatif dalam penelitian ini yaitu jenis penelitian dengan menggunakan data-data subtansi atau angka sebagai bahan perbandingan maupun bahan rujukan. Penelitian dilaksanakan di Kelurahan Lembo Kecataman Tallo Kota Makassar pada bulan Desember 2018 - Juni 2019.

Tahapan pengumpulan data mencakup observasi lapangan, wawancara, data instansional dan kepustakaan. Seluruh data yang diperoleh kemudian dikelompokkan berdasarkan kebutuhan data yang digunakan. Batasan data mencakup data kependudukan, data kondisi fisik wilayah dan data penggunaan lahan. Tahapan pengumpulan data dilakukan dengan melalukan digitasi pemanfaatan lahan di Kelurahan Lembo, sehingga diperoleh lahan terbangun dan tidak terbangun. Selanjutnya mengidentifikasi jenis RTH baik privat dan publik dari data luas tidak terbangun. Hasil digitasi tersebut kemudian disesuiakan dengan kondisi eksisting di lapangan dengan survei secara langsung dan terstruktur.

Berdasarkan tujuan penelitian, maka digunakan dua alat analisis sesuai dengan data yang tersedia. Analisis deskriptif kualitatif digunakan untuk menggambarkan atau menguraikan secara jelas bagaimana potensi ketersediaan ruang terbuka hijau (RTH) didasarkan oleh Peraturan Menteri Pekerjaan Umum Nomor: 05/PRT/M/2008 tentang Pedoman Penyediaan dan Pemanfaatan Ruang Terbuka Hijau di Kawasan Perkotaan. Standar peruntukan RTH dengan mempertimbangkan nilai $30 \%$ dari luas wilayah.

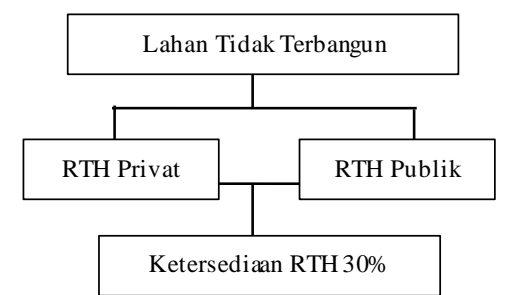

Gambar 1. Alur analisis ketersediaan RTH

Selanjutnya hasil dari analisis pertama kemudian dilanjutkan dengan Analisis Overlay menggunakan Sistem Informasi Geografis. Analisis ini dilakukan dengan tujuan agar pemanfaatan lahan RTH di Kelurahan Lembo dimanfaatkan sesuai dengan peruntukannya. Dengan melakukan overlay peta maka diharapkan akan menghasilkan suatu gambaran yang jelas ketersediaan ruang terbuka hijau di lokasi penelitian. Tahapan penelitian disajikan pada gambar berikut.

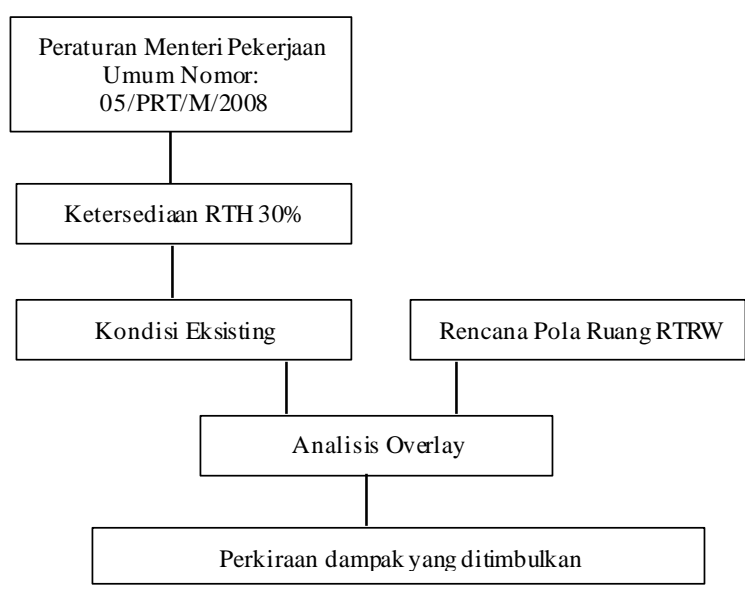

Gambar 2. Alur a nalisis overlay 


\section{HASIL DAN PEMBAHASAN}

\subsection{Gambaran Umum}

Kelurahan Lembo termasuk dalam wilayah Kecamatan Tallo yang terdiri atas 5 RW dan 32 RT yang mempunyai luas wilayah sebesar 47,57 ha. Adapun batas administratif Kelurahan Lembo sebelah Utara berbatasan dengan Kelurahan Pannampu, sebelah timur berbatasan dengan Kelurahan Suwannga, sebelah selatan berbatasan dengan Kelurahan Kalukuang dan sebelah barat berbatasan dengan Kelurahan Bunga Eja Beru.

Jenis tanah yang ada di Kelurahan Lembo adalah jenis tanah inceptisol, tanah inceptisol ini merupakan tanah yang termasuk dalam kategori tanah alluvial dan merupakan suatu jenis tanah muda yang juga termasuk ke dalam jenis tanah mineral.

Kelurahan Lembo memiliki kemiringan lereng antara $0-2 \%$ dengan ketinggian $0-2 \mathrm{mdpl}$ Dengan kondisi topografi yang ladai akan mendukung kegiatan pembangunan ataupun pengelolaan lahan di Kelurahan Lembo. Jumlah penduduk di Kelurahan Lembo untuk akhir tahun 2017 adalah 11.625 jiwa dengan tingkat kepadatan penduduk yaitu $89.423 \mathrm{jiwa} / \mathrm{Km}^{2}$. Untuk jumlah penduduk terbesar yaitu pada tahun 2015 dengan jumlah penduduk sebesar 11.941 jiwa.

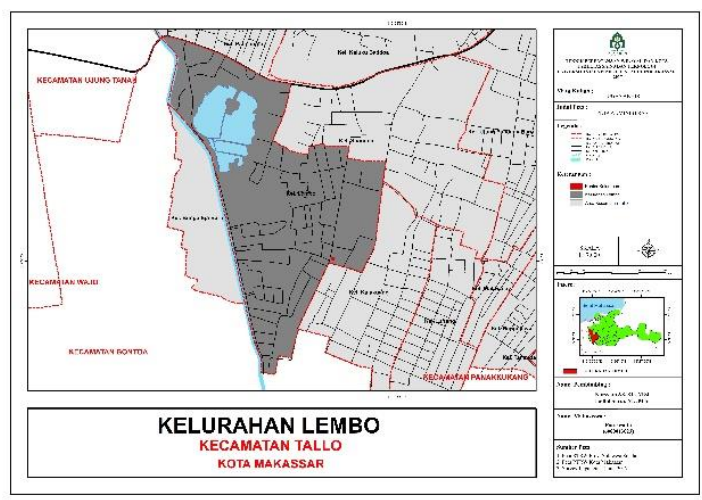

Gambar 3. Peta a dministrasi Kelura han Lembo

\subsection{Pemanfaatan Lahan}

Kondisi pemanfaatan lahan di Kelurahan Lembo diukur berdasarkan tingkat perbandingan antara lahan terbangun dan lahan tidak terbangun. Perhitungan luas lahan terbangun dan tidak terbangun berpengaruh terhadap perkembangan dan pengembangan suatu kawasan ataupun wilayah.

Lahan tidak terbangun terdiri dari sawah, RTH (sempadan sungai/kanal, taman bermain, lapangan olahraga) dan pemakaman. Sedangkan lahan terbangun terdiri dari permukiman dan sarana yang mendukung permukiman. Berdasarkan hasil survei pada Kelurahan Lembo, luas lahan yang dibangun terdiri dari:

- Lahan terbangun : $35.48 \mathrm{Ha}$

- Lahan tidak terbangun : $12.09 \mathrm{Ha}$

- Luas lahan total $: 47.57 \mathrm{Ha}$

Distribusi lahan terbangun mencakup lahan permukiman, fasilitas kesehatan, peribadatan, sarana olahraga dan perkantoran. Dominasi pemanfaatan lahan terbangun adalah kegiatan permukiman yang mencapai $96,76 \%$ dari luas lahan terbangun. Berdasarkan karakteristik fisiknya Kelurahan Lembo merupakan salah satu kelurahan dengan dominan intensitas bangunan yang berfungsi sebagai perdagangan dan jasa. Hal ini sejalan dengan letak strategis Kelurahan Lembo dalam tataran wilayah Kota Makassar.

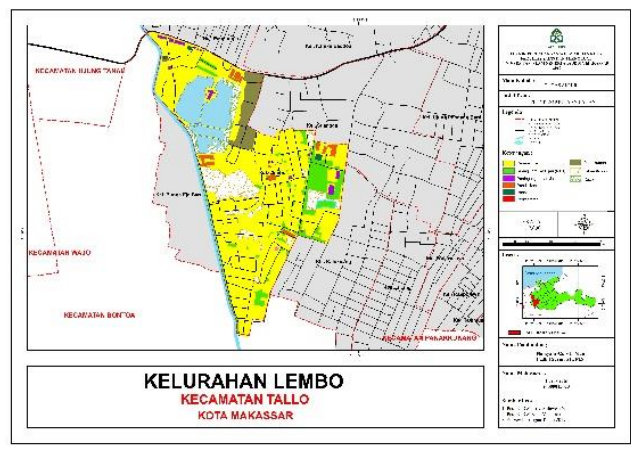

Gambar 4. Peta penggunaan lahan

Tabel 1. Distribusi lahan terbangun tahun 2019

\begin{tabular}{ccc}
\hline Jenis & Luas $\left(\mathrm{km}^{2}\right)$ & Persen \\
\hline Permukiman & 34.33 & 96.76 \\
Pendidikan & 0.86 & 2.42 \\
Kesehatan & 0.03 & 0.08 \\
Peribadatan & 0.15 & 0.42 \\
Gedung olahraga & 0.09 & 0.25 \\
Perkantoran & 0.02 & 0.06 \\
Jumlah & 35,48 & 100 \\
\hline Sumber:
\end{tabular}

Sumber: digitasi, 2019. 
Sedangkan lahan tidak terbangun dengan luas total $12,09 \%$ didominasi oleh tubuh air berupa danau yang mencapai 5,33 ha atau 44,09\% dari luas lahan tidak terbangun. Selebihnya berupa lapangan olahraga, rawa dan lahan kosong. Lahan yang tidak dimanfaatkan tersebut berpeluang sebagai area pengembangan RTH. Namun masih harus dimiliki oleh pemerintah.

Tabel 2. Distribusilahan tak terbangun tahun 2019

\begin{tabular}{ccc}
\hline Jenis & Luas $\left(\mathrm{km}^{2}\right)$ & Persen \\
\hline Lapangan olahraga & 1.04 & 8.60 \\
Rawa & 1.54 & 12.74 \\
Danau & 5.33 & 44.09 \\
Lahan kosong & 4.18 & 34.57 \\
Jumlah & 12,09 & 100 \\
\hline
\end{tabular}

Sumber: digita si, 2019.

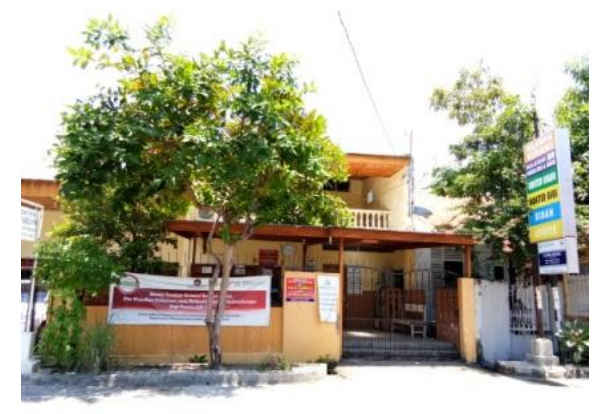

Gambar 5. Jenis ba ngunan sarana kesehatan

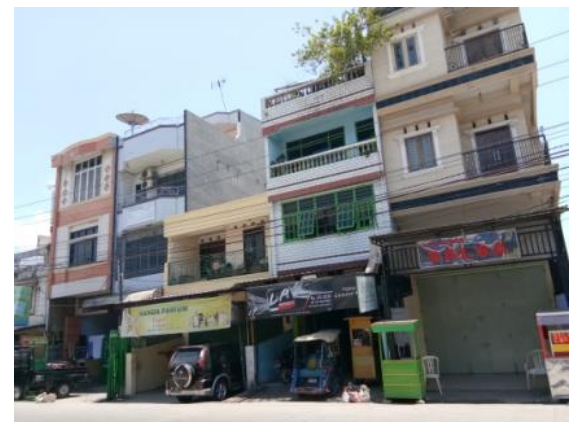

Gambar 6. Jenis ba ngunan sarana perdagangan

\subsection{Jenis RTH}

Ruang terbuka hijau kota adalah bagian dari ruang-ruang terbuka suatu wilayah perkotaan yang diisi oleh tumbuhan, tanaman, dan vegetasi guna mendukung manfaat langsung atau tidak langsung yang dihasilkan oleh RTH dalam kota tersebut yaitu keamanan, kenyamanan, kesejahteraan, dan keindahan wilayah perkotaan tersebut (Departemen Pekerjaan Umum, 2008).

Manfaat kehidupan dapat diperoleh dengan keberadaan RTH perkotaan. Sesuai dengan UndangUndang No.26 Tahun 2007 tentang Penataan Ruang dan Peraturan Menteri PU No.05/PRT/M/2008 tentang Pedoman Penyediaan dan Pemanfaatan Ruang Terbuka Hijau di Kawasan Perkotaan, rencana tata ruang wilayah kota harus memuat rencana penyediaan dan pemanfaatan ruang terbuka hijau yang luas minimalnya adalah sebesar $30 \%$ dari luas wilayah kota.

Terkait dengan berbagai fungsi penting dari keberadaan RTH antara lain adalah fungsi ekologis, sosial, ekonomi, dan arsitektural. Selain dari nilai estetikanya keberadaan RTH yang utama adalah manfaatnya dalam meningkatkan kualitas lingkungan untuk kelangsungan kehidupan perkotaan dalam menciptakan kota yang berkelanjutan.

Menurut Permen PU Nomor 05 Tahun 2008 tentang Pedoman Penyediaan dan Pemanfaatan Ruang Terbuka Hijau di Kawasan Perkotaan adalah bentuk RTH dapat diklasifikasikan menjadi bentuk:

- RTH alami (habitat liar/alami, kawasan lindung),

- RTH non alami atau RTH binaan (pertanian kota, pertamanan kota, lapangan olahraga, pemakaman),

Berdasarkan sifat dan karakter ekologisnya diklasifikasikan menjadi bentuk area kawasan (areal) dan bentuk RTH jalur (koridor). Berdasarkan penggunaan lahan atau kawasan fungsionalnya diklasifikasikan menjadi RTH kawasan perdagangan, RTH kawasan perindustrian, RTH kawasan permukiman, RTH kawasan pertanian, dan RTH kawasankawasan khusus, seperti pemakaman, olahraga, alamiah.

Berdasarkan status kepemilikan RTH diklasifikasikan menjadi RTH publik, yaitu RTH yang berlokasi pada lahan-lahan publik atau lahan yang dimiliki oleh pemerintah dan RTH privat atau non publik, yaitu yang berlokasi pada lahan-lahan milik pribadi. Berdasarkan kondisi eksisting di lapangan, 
dapat diuraikan jenis RTH di Kelurahan Lembo.

\subsubsection{Taman Kota}

Berdasarkan hasil survei lapangan, bahwa untuk RTH taman kota dapat dimanfaatkan penduduk yang ada di Kelurahan Lembo untuk melakukan berbagai kegiatan sosial. Taman ini dapat berbentuk sebagai RTH (lapangan hijau), yang dilengkapi dengan fasilitas utama lapangan olahraga. Luas lapangan olahraga yang ada di Kelurahan Lembo sebesar 1.12 Ha dengan minimal RTH $30 \%$ dan terletak di tengah-tengah permukiman.

Taman ini terletak di tengah-tengah permukiman, dimana pemanfaatan aktivitas utamanya adalah tempat bermain sepak bola, badminton, tennis, jalur trek lari di seputarnya dan bermain bola basket, serta kegiatan yang lebih bersifat pasif, misalnya duduk dan bersantai yang didominasi oleh ruang hijau dengan pepohonan.

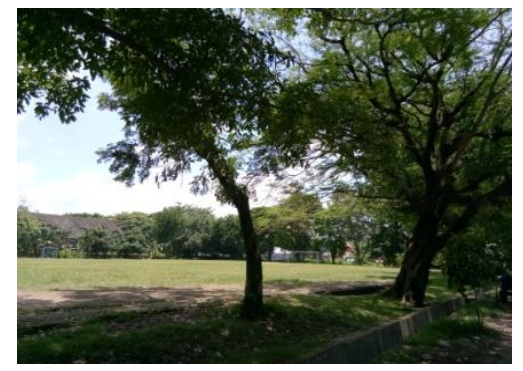

Gambar 7. Taman kota

\subsubsection{Jalur Hijau}

RTH dapat disediakan dengan penempatan tanaman antara 20-30\% dari ruang milik jalan. Jalur hijau jalan yang ada di Kelurahan Lembo sebesar $2.44 \%$ dan terletak di sempadan jalan, dimana selain berfungsi sebagai RTH, pulau jalan atau median jalan juga bisa berfungsi sebagai wilayah konservasi air dan penahan debu untuk keindahan/estetika kota.

\subsubsection{Sumber Air Baku}

RTH sumber air baku meliputi sungai, danau/waduk, dan mata air. Untuk danau dan waduk yang berada di Kelurahan Lembo sebesar 5.33 Ha dan terletak di tengah-tengah permukiman, dimana RTH terletak pada garis sempadan yang ditetapkan sekurang-kurangnya 50 meter dari titik pasang tertinggi ke arah darat. Keberadaan waduk ini berfungsi sebagai dalam menjaga kestabilan tata air, sumber air baku yang dikelola oleh PDAM sekaligus menjadi area wisata dan rekreasi bagi masyarakat sekitar untuk kegiatan memancing.

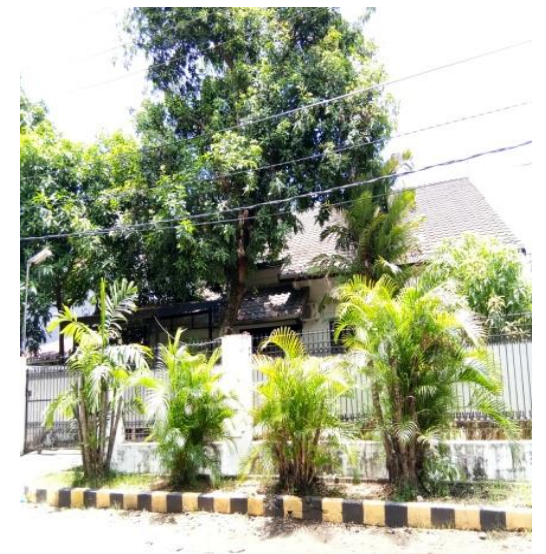

Gambar 8. Jalurhijau

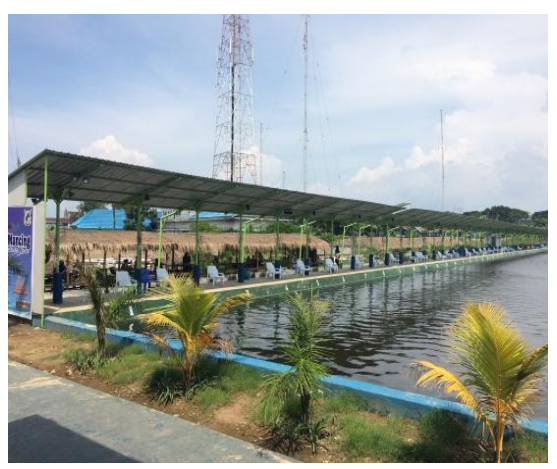

Gambar 9. Waduk/ sumber a ir baku

\subsubsection{Halaman Tempat Usaha}

RTH halaman tempat usaha umumnya berupa jalur trotoar dan area parkir terbuka, dapat dimanfaatkan pula sebagai tempat untuk menyelenggarakan berbagai aktivitas di luar ruangan seperti bazar, olahraga, dan lain-lain. Adapun luas RTH halaman tempat usaha di Kelurahan Lembo sebesar 0.67 Ha atau 1.24\% dan terletak di depan rumah salah seorang penduduk yang memiliki halaman tempat usaha.

\subsubsection{Pemakaman}

Penyediaan RTH pada areal pemakaman disamping memiliki fungsi utama sebagai tempat penguburan jenazah juga memiliki fungsi ekologis yaitu sebagai daerah resapan air, tempat pertumbuhan berbagai jenis vegetasi, dimana luas RTH pemakaman yang 
ada di Kelurahan Lembo sebesar $2.43 \mathrm{Ha}$ dan terletak di tengah-tengah permukiman.

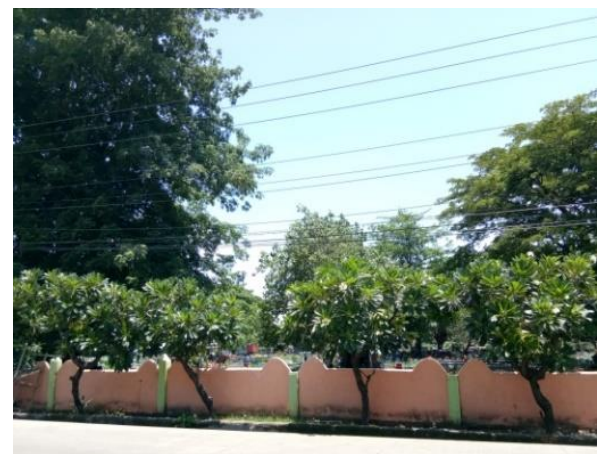

Gambar 10. Pemakaman

\subsubsection{Pekarangan}

Luas pekarangan disesuaikan dengan ketentuan koefisien dasar bangunan (KDB). Luas pekarangan yang ada di Kelurahan Lembo sebesar $1.52 \mathrm{Ha}$ dan terletak di halaman depan rumah salah seorang penduduk yang memiliki pekarangan, dimana RTH pada rumah dengan pekarangan luas dapat dimanfaatkan sebagai tempat utilitas tertentu (sumur resapan) dan dapat juga dipakai untuk tempat menanam tanaman hias.

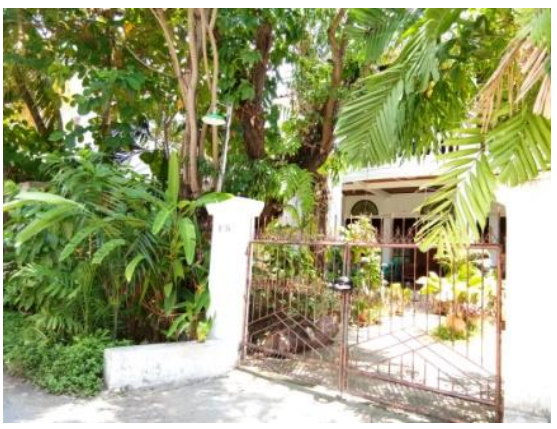

Gambar 11.Pekarangan rumah warga

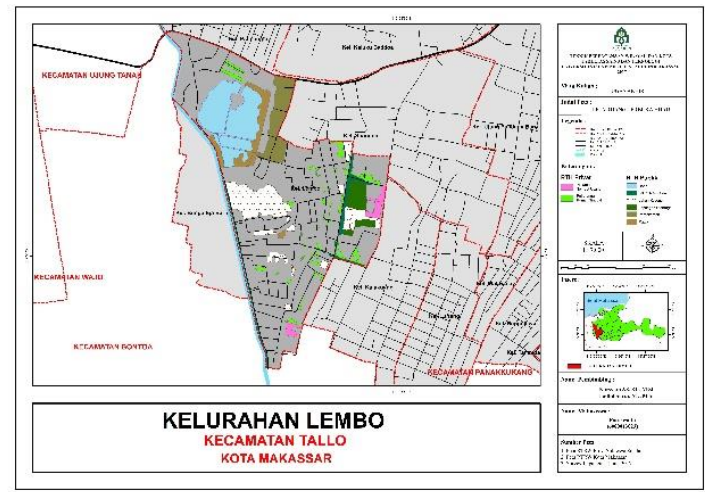

Gambar 12. Sebaran RTH

\subsection{Ketersediaan RTH}

Pengukuran ketersediaan RTH menggunakan 2 pendekatan kebijakan yaitu UU Nomor 26 Tahun 2007 tentang penataan ruang dan Peraturan Menteri Pekerjaan Umum Nomor: 05/PRT/M/2008 tentang pedoman penyediaan dan pemanfaatan ruang terbuka hijau di kawasan perkotaan. Keduanya mensyaratkan luas minimal RTH kawasan perkotaan yang terdiri dari RTH publik 20\% dan RTH privat minimal $10 \%$. Sehingga berdasarkan klasifikasi jenis RTH dapat diidentifikasi ketersediaan RTH di tingkat Kelurahan Lembo dengan pendekatan 2 kebijakan tersebut. Ketersediaan RTH diukur berdasarkan jenis RTH privat dan RTH publik yang telah diklasifikasi.

Tabel 3. Distribusi RTH publik tahun 2019

\begin{tabular}{ccc}
\hline Jenis & Luas $\left(\mathrm{km}^{2}\right)$ & Persen \\
\hline Lapangan olahraga & 1.12 & 2.07 \\
Lahan kosong & 4.18 & 7.74 \\
Pemakaman & 2.43 & 4.50 \\
Rawa & 1.54 & 2.85 \\
Jalur hijau jalan & 1.32 & 2.44 \\
Danau & 5.33 & 9.87 \\
Jumlah & 15,92 & $29,48 \%$ \\
\hline \multicolumn{3}{c}{ Sumber: analisis, 2019. }
\end{tabular}

Tabel 4. Distribusi RTH privat tahun 2019

\begin{tabular}{ccc}
\hline Jenis & Luas $\left(\mathrm{km}^{2}\right)$ & Persen \\
\hline $\begin{array}{c}\text { Halaman Tempat } \\
\text { Usaha }\end{array}$ & 0.67 & 1,24 \\
$\begin{array}{c}\text { Pekarangan Rumah } \\
\text { Tinggal } \\
\text { Jumlah }\end{array}$ & 1.52 & 2.81 \\
\multicolumn{2}{c}{ Sumber: analisis, 2019. }
\end{tabular}

Dalam skala lingkungan permukiman, sesuai dengan Permen PU tersedianya ruang terbuka hijau dalam secara berjenjang sesuai tingkat kewilayahannya, tingkat Rukun Tetangga (RT), Rukun Warga (RW), maupun tingkat kota. Pekarangan atau halaman rumah, luasnya secara umum diatur dalam rencana $\mathrm{KDH}$ dengan ideal besarnya KDH adalah $30 \%$ sehingga $30 \%$ dari luas kapling merupakan RTH yang memiliki fungsi estetis sebagai pelembut bangunan, fungsi ekologis sebagai peneduh, menjamin peresapan air hujan, mencegah erosi percik, pengubah iklim mikro, 
penyerap timbal, $\mathrm{CO}_{2}$, penyaring debu dan kebisingan, penahan angin serta mengurangi silau matahari.

RTH publik dan RTH privat eksisting di Kelurahan Lembo sudah terpenuhi yang telah ditetapkan oleh UU Nomor 26 Tahun 2007 tentang penataan ruang. Luas RTH publik Kelurahan Lembo adalah seluas $15.92 \mathrm{Ha}$ atau setara dengan $29.48 \%$, sedangkan luas RTH privat Kelurahan Lembo adalah seluas $2.19 \mathrm{Ha}$ atau setara dengan $4 \%$, dan luas keseluruhan RTH yang ada di Kelurahan Lembo saat ini sebesar $18.12 \mathrm{Ha}$ atau setara dengan $33.56 \%$ sehingga dari sisi kebutuhan luas area hijau untuk ruang terbuka hijaunya telah tersedia dan memenuhi syarat yang telah di tetapkan oleh UU Nomor 26 Tahun 2007 tentang penataan ruang, yang mensyaratkan luas RTH minimal $30 \%$ dari total luas wilayah.

\subsection{RTH dan Rencana Pola Ruang}

Pemanfaatan ruang adalah upaya untuk mewujudkan struktur ruang dan pola ruang sesuai dengan rencana tata ruang melalui penyusunan dan pelaksanaan program beserta pembiayaannya (UU Nomor 26 Tahun 2007). Peraturan zonasi merupakan ketentuan yang mengatur pemanfaatan ruang dan unsur-unsur pengendalian yang disusun untuk setiap zona peruntukan sesuai dengan rencana rinci tata ruang. Peraturan zonasi (Zoning Regulation) adalah ketentuan yang mengatur tentang klasifikasi zona, pengaturan lebih lanjut mengenai pemanfaatan lahan, dan prosedur pelaksanaan pembangunan (Barnet, 1982 dalam Asyiawati \& Evi, 2014).

Analisis superimpose dilakukan untuk menilai kesesuaian peruntukan lahan secara keseluruhan terhadap rencana pola ruang. Hal ini penting dilakukan agar menjadi alternatif dalam menjaga keberadaan RTH saat ini. RTH di Kelurahan Lembo saat ini yang masih tersedia dalam skala kelurahan sehingga perlu dijaga eksistensinya. Perkembangan dan pertumbuhan kota/perkotaan disertai dengan alih fungsi lahan yang pesat, telah menimbulkan kerusakan lingkungan yang dapat menurunkan daya dukung lahan dalam menopang kehidupan masyarakat di kawasan perkotaan, sehingga perlu dilakukan upaya untuk menjaga dan meningkatkan kualitas lingkungan melalui penyediaan RTH yang memadai (Permendagri, Nomor 1 Tahun 2007).

Tabel 4. Perbandingan eksisting pada la han terbangun dengan rencana pola ruang

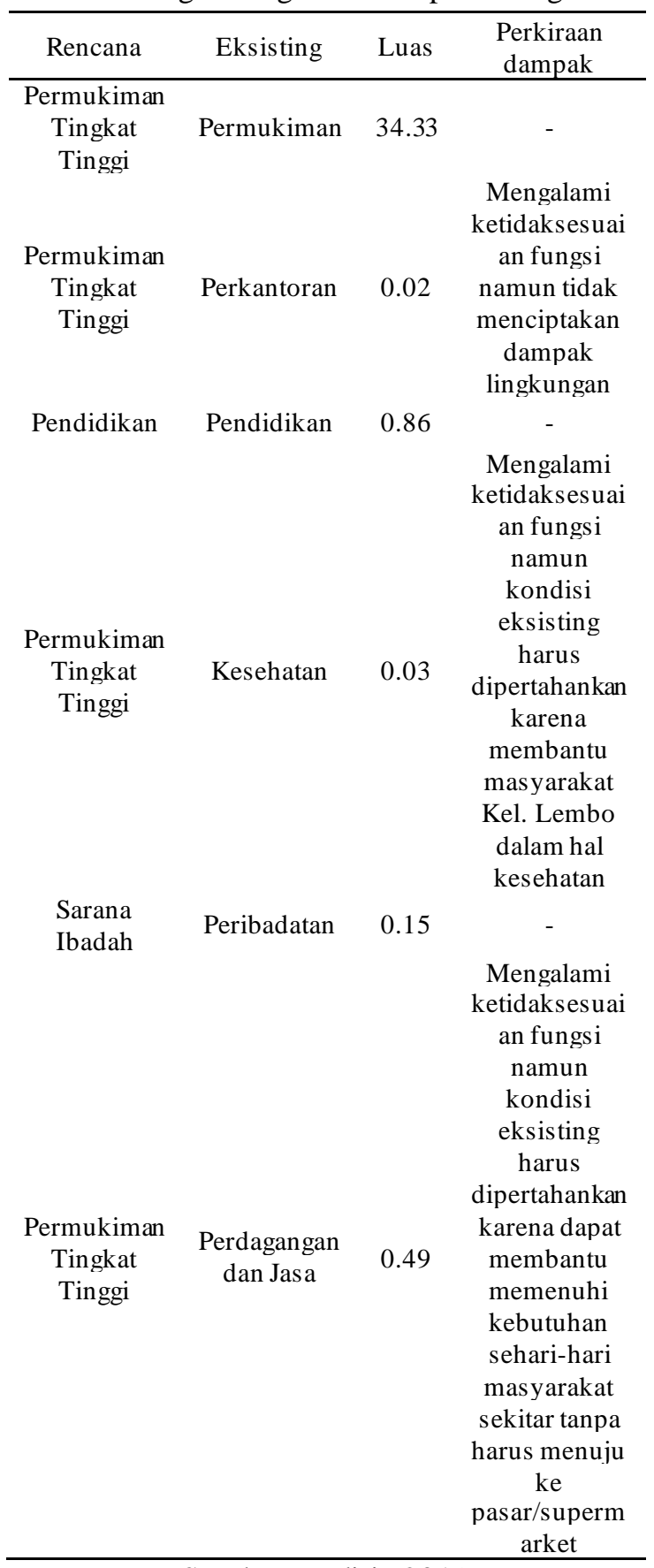

Sumber: analisis, 2019.

Secara umum hasil overlay dari pola ruang dengan eksisiting penggunaan lahan diperoleh perkiraan dampak yang tidak signifikan terhadap kondisi lingkungan secara umum. Beberapa atribut perencanaan pada pola ruang RTRW Kota Makassar yang mengalami 
ketidaksesuaian hanya pada rencana permukiman tingkat tinggi dengan eksisting perkantoran, kesehatan serta perdagangan/jasa Total luasan untuk rencana permukiman tingkat tinggi mencapai $0,54 \mathrm{~km}^{2}$.

Tabel 5. Perbandingan eksisting pada lahan tidak terbangun dengan rencana pola ruang

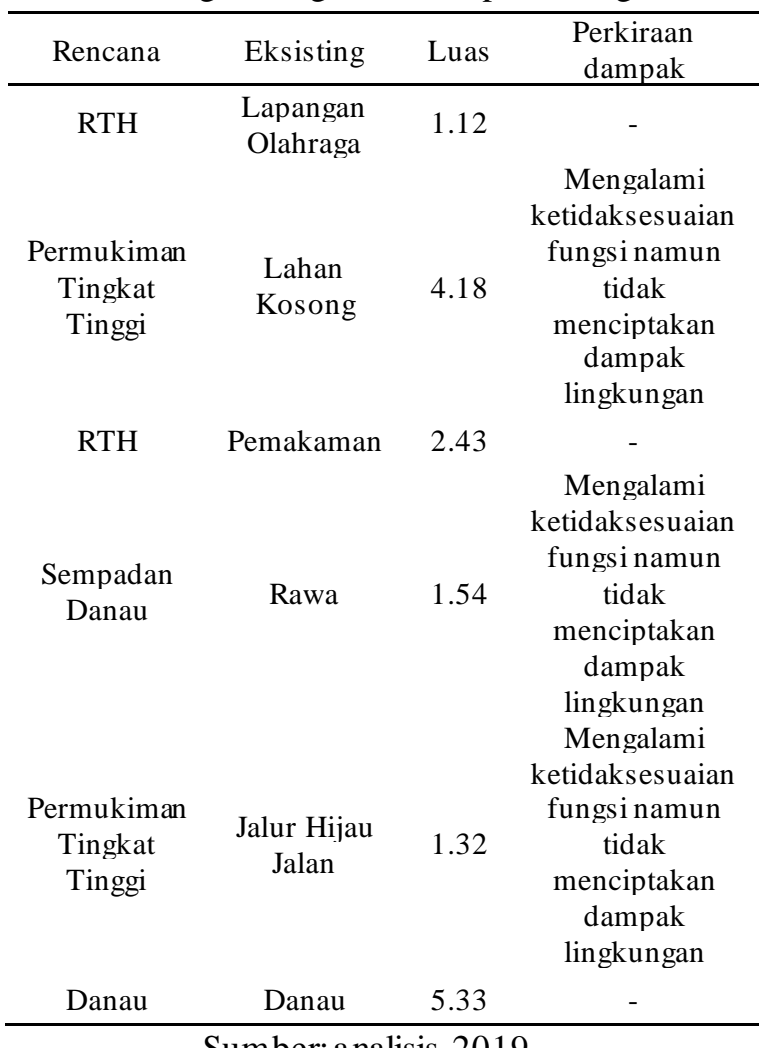

Sumber: a nalisis, 2019 .

Total luasan eksisting pada lahan non terbangun tidak memiliki perkiraan dampak terhadap lingkungan. Atribut yang mengalami ketidaksesuaian yaitu permukiman tingkat tinggi dan sempadan danau. Berdasarkan hasil overlay pada tabel di atas, diperoleh informasi bahwa secara umum perbandingan antara lahan eksisting dengan rencana pola ruang dari Peraturan Daerah Kota Makassar Nomor 6 Tahun 2006 tentang Rencana Tata Ruang Wilayah (RTRW) Kota Makassar Tahun 2005-2015 tidak mengalami penyimpangan yang siginifikan.

Distribusi kawasan lindung dalam kondisi stabil, dimana tidak terjadi ketidaksesuaian pemanfaatan lahan dengan kondisi eksisting. Distribusi kawasan budidaya dari rencana pola ruang mengalami pergeseran pemanfaatan lahan terutama pada kawasan budidaya untuk permukiman tingkat tinggi. Secara eksisting masih difungsikan sebagai perkantoran, sarana kesehatan serta perdagangan dan jasa. Keberadaan lahan kosong juga menjadi peluang memaksimalkan RTH saat ini.

Dimana dari rencana pola ruang diarahkan untuk permukiman tingkat tinggi namun secara eksisiting lahan ini belum dimanfaatkan. Sehingga secara keseluruhan dukungan kebijakan dalam pola ruang dapat memberikan dorongan penuh dalam mempertahankan keberadaan RTH di Kelurahan Lembo saat ini. Permasalahan pegelolaan RTH di perkotaan salah satunya diakibatkan oleh tinggi alihfungsi lahan atau ketidaksesuaian antara rencana dan kondisi eksisting.

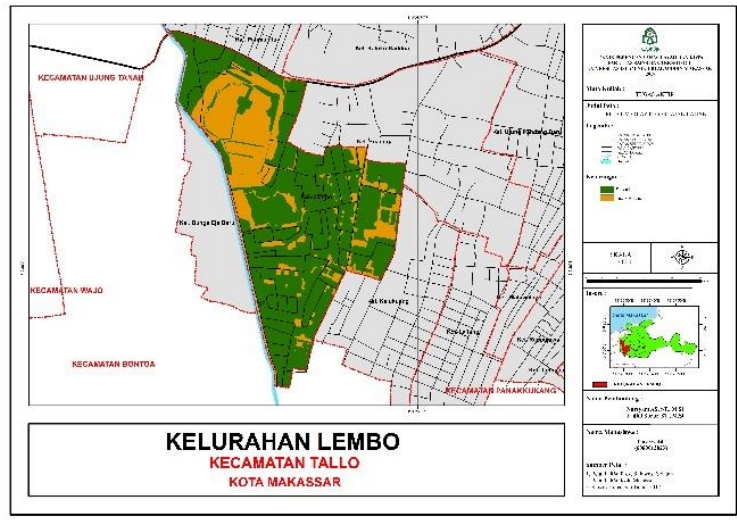

Gambar 13. Hasiloverlay dengan Pola Ruang

Ketersediaan RTH merupakan lahan yang sering diganti atau dirubah manfaat fungsinya menjadi lahan terbangun, dengan alasan perkembangan atau pembangunan kota. Hal ini sering terjadi karena RTH kota sering dianggap sebagai lahan yang tidak memiliki manfaat, sehingga dapat mudah dikonversi menjadi berbagai bentuk pembangunan fisik tanpa harus dengan ganti rugi tanah yang membutuhkan biaya yang sangat besar. Masyarakat kota saat ini menjadi semakin sulit untuk mendapatkan RTH yang dapat dimanfaatkan secara fungsional, fisik, ekologis, dan sosial. Ketersediaan RTH sudah semakin jauh dari standar kebutuhan yang di peruntukkan bagi masyarakat perkotaan, padahal RTH memberikan kontribusi yang tidak sedikit dalam meningkatkan kualitas lingkungan kota (Putra, 2012).

Kualitas RTH pada 30 tahun terakhir, mengalami penurunan. Menurunnya kuantitas dan kualitas tersebut telah mengakibatkan 
menurunnya kualitas lingkungan perkotaan seperti seringnya terjadi banjir di perkotaan, tingginya polusi udara, dan meningkatnya kerawanan sosial, serta menurunnya produktivitas masyarakat akibat gangguan psikologis karena terbatasnya ruang yang tersedia untuk interaksi sosial (Imansari \& Khadiyanta, 2013). Ketersediaan lahan untuk permukiman di perkotaan yang semakin sempit sedangkan jumlah penduduk semakin meningkat dengan cepat menyebabkan kotakota besar di Indonesia terdapat banyak kawasan permukiman padat (Amin \& Amri, 2011).

Perencanaan ruang terbuka hijau (RTH) didasarkan pada pertimbangan dapat terwujudnya keseimbangan, keserasian, dan keselamatan bangunan gedung dengan lingkungan di sekitarnya, serta mempertimbangkan terciptanya ruang luar bangunan gedung dan ruang terbuka hijau yang seimbang, serasi, dan selaras dengan lingkungan di sekitarnya (Suripin, 2004). Sebagai bagian dari rencana tata ruang, maka kedudukan RTH akan menjadi penentu keseimbangan lingkungan hidup dan lingkungan binaan karena RTH merupakan paru-paru kota. Rencana tata ruang menjadi landasan dalam mengantisipasi pesatnya perkembangan ruang-ruang terbangun, yang harus diikuti dengan kebijakan penyediaan ruang terbuka (Samsudi, 2010). Pengembangan RTH di kawasan perkotaan dapat memanfaatkan lahan yang tidak terbangun sesuai dengan peruntukan dari rencana tata ruang (Aswar, Beddu, \& Surur, 2019).

Tata ruang yang diharapkan dapat mengakomodasi seakan tidak berdaya menahan mekanisme pasar (Zulfikar, 2017). Sejumlah areal di perkotaan, dalam beberapa dasawarsa terakhir ini, ruang publik, telah tersingkir akibat pembangunan gedung-gedung yang cenderung berpola container (container development) yakni bangunan yang secara sekaligus dapat menampung berbagai aktivitas sosial ekonomi, seperti mall, perkantoran, hotel, dan sebagainya, yang berpeluang menciptakan kesenjangan antar lapisan masyarakat (Supratiwi, 2018).

\section{KESIMPILAN}

Ketersediaan ruang terbuka hijau di Kelurahan Lembo sebagaimana diamanatkan Peraturan Menteri Pekerjaan Umum Nomor 05 Tahun 2008 tentang Pedoman Penyediaan dan Pemanfaatan Ruang Terbuka Hijau di Kawasan Perkotaan yaitu RTH publik minimal 20\% dan RTH privat sebesar $10 \%$ dari luas lahan keseluruhan sudah memenuhi syarat. Pengukuran secara empiris terhadap luas lahan keseluruhan dan pengukuran secara cermat luas RTH publik dan RTH privat menjadi kunci dalam merumuskan justifikasi terpenuhi atau tidaknya lahan terbuka hijau di Kelurahan Lembo sebagai syarat lingkungan perumahan dapat mengakomodasi kebutuhan ruang terbuka hijau bagi penghuninya. Harapan akan adanya regulasi / aturan yang dapat dijadikan sebagai pedoman dalam pengembangan dan penataan RTH di Kelurahan Lembo Kecamatan Tallo Kota Makassar sehingga mampu turut serta menciptakan kota yang berwawasan lingkungan.

\section{UCAPAN TERIMAKASIH}

Penelitian ini dilakukan dengan dukungan dari berbagai pihak terutama dalam proses pengambilan data di lapangan antara lain Pemerintah Kelurahan Lembo, Pemerintah Kecamatan Tallo, data ruang terbuka hijau dan kebijakan penataan ruang dari Badan Lingkungan Hidup Kota Makassar, Badan Perencanaan Pembangunan Daerah, Dinas Pekerjaan Umum dan Penataan Ruang serta data relevan lainnya. Selanjutnya kepada kelompok masyarakat baik level pemuda dan lembaga formal lainnya yang turutserta berpartisipasi. Ucapan terima kasih pada Pusat Studi Tata Lingkungan dan Kependudukan Universitas Islam Negeri Alauddin Makassar yang telah memfasilitasi proses analisis dan interpretasi hasil pengambilan data di lapangan.

\section{REFERENSI}

Amin, S., \& Amri, N. (2011). Evaluasi Ketersediaan Ruang Terbuka Hijau Di Kompleks Perumahan Bumi Permata Sudiang Kota Makassar. Prosiding Hasil Penelitian Fakultas Teknik Universitas Hasanuddin, 1-12. 
Arifin, S. S. (2014). Analisis Kebutuhan Ruang Terbuka Hijau Kecamatan Kota Tengah Kota Gorontalo. RADIAL juRnal perADaban saIns, rekayAsa dan teknoLogi, 27-32.

Aswar, M., Beddu, S., \& Surur, F. (2019). Ketersediaan dan Kebutuhan Ruang Terbuka Hijau Publik di Kelurahan Polewali Kabupaten Polewali Mandar. Jurnal Plano Madani, 206-216.

Asyiawati, Y., \& Evi, N. (2014). Strategi Pengendalian Pemanfaatan Lahan Sekitar Kawasan Kalimalang Kota Bekasi Secara Berkelanjutan. Jurnal Perencanaan Wilayah dan Kota, 1-12.

Fahreza, W., \& Restu. (2016). Analisis Ruang Terbuka Hijau Perumahan Nasional Di Kota Medan. Jurnal Geografi, 1-12.

Hadmaja, B. J., \& Kuspriyanto. (2014). Dampak Perkembangan Wilayah Kota Terhadap Ketersediaan Ruang Terbuka Hijau (RTH) Di Kota Mojokerto. Swara Bhumi, 82-89.

Ikhsan, S., \& Aida, A. (2011). Analisis SWOT Untuk Merumuskan Strategi Pengembangan Komoditas Karet Di Kabupaten Pulang Pisau. Jurnal Agribisnis Perdesaan, 9-12.

Imansari, N., \& Khadiyanta, P. (2013). Penyediaan hutan kota dan taman kota sebagai ruang terbuka hijau (RTH) publik menurut preferensi masyarakat di kawasan pusat Kota Tangerang. Jurnal Ruang, 101-110.

Martopo, S., \& Fandeli, C. (1995). Analisis Mengenai Dampak Lingkungan: Prinsip Dasar dan Pemaparannya Dalam Pembangunan. Jakarta: Liberty.

Muta'ali, L. (2012). Daya Dukung Lingkungan Untuk Perencanaan Pengembangan Wilayah. Yogyakarta: Penerbit Fakultas Geografi. Universitas Gadjah Mada.

Pemerintah Republik Indonesia. (2007). Undang - undang Nomor 26 Tahun 2007 tentang Penataan Ruang. Jakarta: Indonesia

Putra, H. P. (2012). Studi Ketersediaan Ruang Terbuka Hijau (RTH) Publik Ibu Kota Kabupaten Majene. Makassar: UIN Alauddin Makassar.
Sabridi, S. (2012). Kajian Subreservoir Air Hujan pada Ruang Terbuka Hijau Dalam Mereduksi Genangan Air (Banjir). Jurnal Permukiman, 176-184.

Salikha, E. (2012). Evaluasi Fungsi Ekologis Ruang Terbuka Hijau (RTH) Di Kota Bandung Dalam Upaya Pengendalian Iklim Mikro Berupa Pemanasan Lokal dan Penyerapan Air (Studi Kasus: Taman-Taman Di WP Cibeunying). Jurnal Perencanaan Wilayah dan Kota, 8-15.

Samsudi, S. (2010). Ruang Terbuka Hijau Kebutuhan Tata Ruang Perkotaan Kota Surakarta. Journal of Rural and Development, 1-12.

Santoso, B., Hidayah, R., \& Sumardjito. (2012). Pola Pemanfaatan Ruang Terbuka Hijau Pada Kawasan Perkampungan Plemburan Tegal, Ngaglik Sleman. Yogyakarta: Pendidikan Teknik Sipil dan Perencanaan Universitas Negeri Yogyakarta.

Soewarno. (2000). Hidrologi Operasional. Yogyakarta: Andi.

Sugiyanto, E., \& Sitohang, C. A. (2017). Optimalisasi Fungsi Ruang Terbuka Hijau Sebagai Ruang Publik Di Taman Ayodia Kota Jakarta Selatan. Jurnal Sosial dan Humaniora, 88-97.

Supratiwi. (2018). Studi Ruang Terbuka Hijau dalam Kebijakan Pengelolaan Lingkungan Hidup Pemerintah Kota Semarang. Jurnal Ilmu Pemerintahan, 22-31.

Suripin. (2004). Pelestarian Sumber Daya Tanah dan Air. Yogyakarta: Andi.

Susilowati, I., \& Nurini, N. (2013). Konsep Pengembangan Ruang Terbuka Hijau (RTH) Pada Permukiman Kepadatan Tinggi. Jurnal Pembangunan Wilayah dan Kota, 429-438.

Kementerian Pekerjaan Umum. (2005). Ruang Terbuka Hijau di Wilayah Perkotaan. Jakarta: Direktorat Jenderal Penataan Ruang Departemen Pekerjaan Umum.

Kementerian Pekerjaan Umum. (2008). Pedoman Penyediaan dan Pemanfaatan Ruang Terbuka Hijau Di Kawasan Perkotaan. Jakarta: Dirjen Penataan Ruang.

Widyaastuti, F. (2012). Analisis Ruang Terbuka Hijau dan Kecukupannya Terhadap 
Jumlah Penduduk Di Kota Bekasi. Bogor: Institut Pertanian Bogor.

Yanti, F. (2016). Kualitas Ruang Terbuka Hijau Publik Di Kota Bandar Lampung (Studi Kasus Lapangan Merah dan Pasar Seni, Lapangan Kalpataru dan Embung Sukarame/Taman Kota). Bandar Lampung: Universitas Lampung.

Zulfikar, W. (2017). Dampak Sosial, Ekonomi Dan Politis Dalam Pembangunan Bandara Udara Kertajati Di Kabupaten Majalengka. Jurnal Caraka Prabu, 5877. 